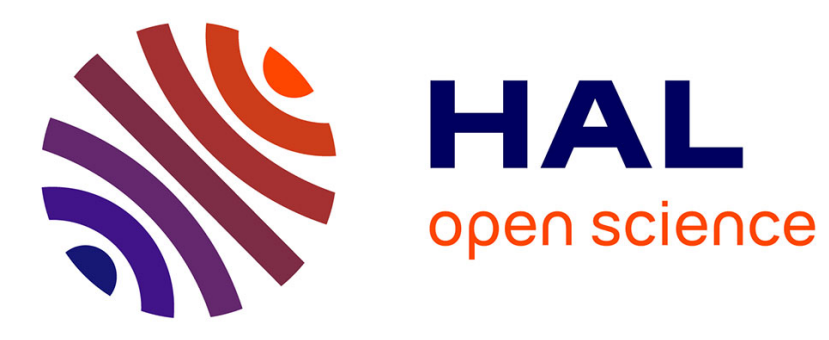

\title{
Are Terrestrial Biological Invasions Different in the Tropics?
}

Kwek Yan Chong, Richard T Corlett, Martin A Nuñez, Jing Hua Chiu, Franck Courchamp, Wayne Dawson, Sara Kuebbing, Andrew M Liebhold, Michael Padmanaba, Lara Souza, et al.

\section{To cite this version:}

Kwek Yan Chong, Richard T Corlett, Martin A Nuñez, Jing Hua Chiu, Franck Courchamp, et al.. Are Terrestrial Biological Invasions Different in the Tropics?. Annual Review of Ecology, Evolution, and Systematics, 2021, pp.291-314. 10.1146/annurev-ecolsys-012021- . hal-03410293

\section{HAL Id: hal-03410293 https://hal.science/hal-03410293}

Submitted on 2 Nov 2021

HAL is a multi-disciplinary open access archive for the deposit and dissemination of scientific research documents, whether they are published or not. The documents may come from teaching and research institutions in France or abroad, or from public or private research centers.
L'archive ouverte pluridisciplinaire HAL, est destinée au dépôt et à la diffusion de documents scientifiques de niveau recherche, publiés ou non, émanant des établissements d'enseignement et de recherche français ou étrangers, des laboratoires publics ou privés. 


\section{Are Terrestrial Biological Invasions Different in the Tropics?}

Kwek Yan Chong ${ }^{1}$, Richard T. Corlett ${ }^{2,3}$, Martin Nuñez ${ }^{4,5}$, Jing Hua Chiu ${ }^{6}$, Franck

Courchamp $^{7}$, Wayne Dawson ${ }^{8}$, Sara Kuebbing ${ }^{9}$, Andrew M. Liebhold ${ }^{10,11}$, Michael

Padmanaba $^{12}$, Lara Souza ${ }^{13}$, Kelly M. Andersen ${ }^{6}$, Songlin Fei ${ }^{14}$, Benjamin P.Y.-H. Lee ${ }^{15}$,

Shawn Lum ${ }^{6}$, Matthew Luskin ${ }^{16}$, Kang Min Ngo ${ }^{6}$, David A. Wardle ${ }^{6}$

${ }^{1}$ Department of Biological Sciences, National University of Singapore. 16 Science Drive 4, Singapore 117558; email: kwek@nus.edu.sg

${ }^{2}$ Center for Integrative Conservation, Xishuangbanna Tropical Botanical Garden, Chinese Academy of Sciences, Menglun, Yunnan 666303, China

${ }^{3}$ Center of Conservation Biology, Core Botanical Gardens, Chinese Academy of Sciences, Menglun, Yunnan 666303, China

${ }^{4}$ Grupo de Ecología de Invasiones, INIBIOMA, CONICET/ Universidad Nacional del Comahue, Av. de los Pioneros 2350, Bariloche 8400, Argentina

${ }^{5}$ Department of Biology and Biochemistry, University of Houston, Houston, Texas, 77204 USA

${ }^{6}$ Asian School of the Environment, Nanyang Technological University. 50 Nanyang Avenue, Singapore 639798; email: david.wardle@ntu.edu.sg

${ }^{7}$ Université Paris-Saclay, CNRS, AgroParisTech, Ecologie Systématique Evolution, 91405, Orsay, France

${ }^{8}$ Department of Biosciences, Durham University, Stockdon Road, Durham, United Kingdom ${ }^{9}$ Department of Biological Sciences, University of Pittsburgh, 4249 Fifth Avenue, Pittsburgh, Pennsylvania, 15206, USA

${ }^{10}$ USDA Forest Service Northern Research Station, 180 Canfield St., Morgantown, WV 26505 USA 
${ }^{11}$ Czech University of Life Sciences, Faculty of Forestry and Wood Sciences, Kamýcká 129, 16500 Prague 6 - Suchdol, Czech Republic

${ }^{12}$ Yayasan Inobu, Jl. Guntur 32 Bogor, West Java 16128, Indonesia

${ }^{13}$ University of Oklahoma, Oklahoma Biological Survey \& Department of Microbiology and Plant Biology, Norman, OK, 73019

${ }^{14}$ Department of Forestry and Natural Resources, Purdue University, West Lafayette, IN 47907 USA

${ }^{15}$ Wildlife Management Division, National Parks Board, 1 Cluny Road, Singapore 259569

${ }^{16}$ School of Biological Sciences, University of Queensland, Brisbane, Qld. 4072, Australia

$\begin{array}{lll}\text { Kwek Yan Chong } & \text { kwek@nus.edu.sg } & \text { https://orcid.org/0000-0003-4754-8957 } \\ \text { Richard T. Corlett } & \text { corlett@xtbg.org.cn } & \text { https://orcid.org/0000-0002-2508-9465 } \\ \text { Martin Nuñez } & \text { nunezm@gmail.com } & \text { https://orcid.org/0000-0003-0324-5479 } \\ \text { Jing Hua Chiu } & \text { jhchiu@ntu.edu.sg } & \\ \text { Franck Courchamp } & \text { franck.courchamp@u-psud.fr } & \text { https://orcid.org/0000-0001-7605-4548 } \\ \text { Wayne Dawson } & \text { wayne.dawson@durham.ac.uk } & \text { https://orcid.org/0000-0003-3402-0774 } \\ \text { Sara Kuebbing } & \text { sara.kuebbing@pitt.edu } & \text { https://orcid.org/0000-0002-0834-8189 } \\ \text { Andrew M. Liebhold } & \text { andrew.liebhold@usda.gov } & \text { https://orcid.org/0000-0001-7427-6534 } \\ \text { Michael Padmanaba } & \text { mpadmanaba@inobu.org } & \\ \text { Lara Souza } & \text { souzaalara@gmail.com } & \text { https://orcid.org/0000-0001-6005-8667 } \\ \text { Kelly M. Andersen } & \text { kelly.andersen.m@gmail.com } & \text { https://orcid.org/0000-0002-1460-9904 } \\ \text { Songlin Fei } & \text { sfei@purdue.edu } & \text { https://orcid.org/0000-0003-2772-0166 } \\ \text { Benjamin P.Y.-H. Lee } & \text { benjamin_lee@nparks.gov.sg } & \\ \text { Shawn Lum } & \text { shawn.lum@ntu.edu.sg } & \text { https://orcid.org/0000-0003-2098-6308 } \\ \text { Matthew Luskin } & \text { mattluskin@gmail.com } & \text { https://orcid.org/0000-0002-5236-7096 } \\ \text { Kang Min Ngo } & \text { kangmin.ngo@ntu.edu.sg } & \text { https://orcid.org/0000-0001-8273-6158 } \\ \text { David A. Wardle } & \text { david.wardle@ntu.edu.sg } & \text { https://orcid.org/0000-0002-0476-7335 }\end{array}$

Authors for correspondence: Kwek Yan Chong (kwek@nus.edu.sg) and David Wardle (david.wardle@ntu.edu.sg)

Running title: Biological Invasions in the Tropics 


\title{
Keywords
}

Latitudinal gradient, biotic invasion, biotic resistance, species characteristics, ecological impacts, biosecurity

\begin{abstract}
Most biological invasion literature — including syntheses and meta-analyses and the resulting theory — is reported from temperate regions, drawing only minimally from the tropics except for some island systems. The lack of attention to invasions in the tropics results from and reinforces the assumption that tropical ecosystems, and especially the continental tropics, are more resistant to invasions. We critically assessed biological invasions in the tropics and compared them with temperate regions, finding relatively weak evidence that tropical and temperate regions differ in their invasibility and in the traits that determine invader success and impacts. Propagule pressure and the traits that promote adaptation to disturbances (e.g., high fecundity or fast growth rates) are generally favorable to invasions in both tropical and temperate regions. We emphasize the urgent need for greater investment and regional cooperation in the study, prevention, and management of biological invasions in the tropics.
\end{abstract}

\section{INTRODUCTION}

\subsection{Invasion Ecology and Tropical Ecology}

Invasive species pose a serious threat to biodiversity and ecosystem functioning (Bellard et al. 2016; Murphy \& Romanuk 2014), and biological invasions continue unabated around the world as a consequence of increased global connectivity (Seebens et al. 2021). Human activities often result in the transport of large numbers of species, either intentionally (e.g., 
through agriculture, horticulture, and the pet trade) or unintentionally (e.g., as hitch-hikers), well beyond the areas that they can reach though natural dispersal. While only a minority of transported species establish self-replacing population that spread far beyond their initial sites of establishment, some that do so can become very abundant and cause declines in native populations and species, transform ecosystems, and impact human well-being (Blackburn et al. 2011).

The tropics are at the frontline of efforts to halt the decline and extinction of species, the degradation of ecosystems, and the erosion of natural capital (Barlow et al. 2018). The tropics contain a majority of the Earth's biodiversity and play a crucial role in the global carbon cycle (Pan et al. 2011). They also have some of the world's highest levels of human developmental pressures but have significant limitations in their financial and institutional capacities to respond to conservation threats (Barlow et al. 2018). Although there have been calls to invest more resources and research into tropical conservation, most attention to date has focused on conservation threats such as habitat loss, land use change, and overexploitation through hunting and logging, while the role of invasive species as an environmental and conservation threat has generally received little attention (Barlow et al. 2018; Gardner et al. 2009), except on some tropical oceanic islands (Courchamp et al. 2003; Russell \& Holmes 2015).

One reason why tropical invasions have not been prioritized is the perception that many tropical ecosystems, notably continental tropical forests, are particularly resistant against invasion (Rejmánek 1996; Teo et al. 2003). Early evidence in support of this was based on the low numbers of naturalized non-native plants (Lonsdale 1999; Rejmánek 1996), birds and mammals (Sax 2001) in the continental tropics compared to higher latitudes. These perceptions about tropical ecosystem resistance to invasion appear entrenched despite the recognition that species introduction and disturbance histories of tropical forests differ from 
those of temperate forests (Denslow \& DeWalt 2008; Fine 2002). Notably, the acceleration in rates of species introductions as well as encroachment by human disturbances that facilitate invasions — such as extensive habitat conversion, fragmentation, and degradation — in tropical interiors is relatively recent compared to many temperate areas, especially in the Northern Hemisphere.

An additional or alternative reason for the low reported numbers of naturalized nonnative species could simply be low investment in research on invasive species in the tropics. The proportion of papers in English addressing invasions in the tropical biology and environmental research literature has been growing at $2.4 \%$ per year on average over the past three decades; on the other hand, the proportion of papers from tropical regions in the invasion biology literature has been growing more slowly at $1.4 \%$ per year (Figure 1a; see Supplemental Material for methods). This disparity suggests that invasive species are being studied by tropical researchers as a faster-growing proportion of their work relative to the proportion of tropical ecosystems being studied by invasion biology researchers. The paucity of tropical studies available to draw on in literature reviews and meta-analyses on various aspects of invasion biology means that the conclusions of these analyses are heavily dominated by the much larger number of studies carried out in temperate regions (Figure 2). Researchers affiliated with institutions in tropical countries do not dominate the authorship of tropical invasion papers (Figure 1b) and tropical countries do not produce more tropical invasion research than do non-tropical countries (Figure 1c). If the lower latitudes are more susceptible to invasions than has been historically assumed, or if they become more susceptible as a consequence of ongoing disturbance, land conversion, and habitat degradation, then the under-representation by local tropical institutions in invasion research and, consequently, the ability to respond to invasive species problems, would be a cause for concern (Early et al. 2016; Seebens et al. 2015). 


\subsection{Aims of This Review}

In this review, we investigate the similarities and differences in biological invasions between tropical and temperate regions. Specifically, we critically examine what is known and not known about the invasibility of tropical habitats, the characteristics of known successful tropical invaders, and the impacts of invasions in tropical areas. We then discuss how best to respond to biological invasions in the tropics in the face of the current socioeconomic context and other high-priority conservation challenges in tropical regions.

\section{INVASIBILITY AND INVADEDNESS OF THE TERRESTRIAL TROPICS}

The concept of invasibility relates to the extent to which an ecosystem fails to resist the establishment of non-native species populations (Lonsdale 1999); it is a key concept in invasion biology but is difficult to measure directly. It is also different from the vulnerability of an ecosystem to impacts by invading species, which we discuss later. Invasibility has mostly been measured by using proxies of the 'degree' (Guo et al. 2015) or 'level' (Catford et al. 2012) of invasion, or hereafter 'invadedness', such as the richness or abundance of naturalized species. However, the invadedness of an ecosystem is a function of both ecosystem invasibility and relative exposure to non-native species (i.e., propagule pressure over time). The low numbers of naturalized non-natives species previously reported from tropical areas (Lonsdale 1999; Rejmánek 1996; Sax 2001) therefore indicate low invadedness at the time of reporting but not necessarily low invasibility. Here we examine whether there is a strong theoretical basis for expecting low invasibility in the tropics and if recent evidence has emerged to support these ideas. 


\subsection{Resource-based Theories}

So far, most explanations of the purportedly low invasibility of tropical relative to temperate ecosystems draw on resource competition-consumption theories. It has been proposed that light limitation in intact tropical forests should exclude non-native plants from establishing in understories (Fine 2002). If light availability is the primary control on tropical invasibility, then open tropical habitats should be more invasible than closed canopy tropical forests. There is some evidence for this pattern, with many records of naturalized plants in open tropical savannas and dry forests (Foxcroft et al. 2010; Kerns et al. 2020) and very few in closed-canopy rainforests (Fine 2002). However, this same light limitation hypothesis has been refuted even for many light-limited temperate forests, because several shade-tolerant invasive plants have been shown to establish and expand into them (Martin et al. 2009).

Belowground resources may also affect the invasibility of tropical ecosystems. Notably, the availability of certain rock-derived nutrients, especially phosphorous, is on average more limiting in tropical ecosystems than in comparable temperate systems, although there are many exceptions (Du et al. 2020). Non-native tree diversity has been found to increase with increasing soil phosphorous, but not with soil nitrogen, in tropical secondary forests on abandoned land in Singapore (Lai et al. 2021). Similarly, in the Brazilian cerrado, non-native plant abundance has been shown to decrease with increasing (foliar) N:P ratio of the vegetation (Lannes et al. 2012), and phosphorous addition with or without nitrogen addition was found to promote invasion by the African grass Melinis minutiflora (Bustamante et al. 2012). These examples suggest that increased phosphorous availability in tropical ecosystems may frequently lead to increased invasion by nutrient-demanding non-native plant species.

Because diversity of most taxonomic groups is higher on average in the tropics, this has been a tempting starting point for explanations of reduced invasibility. High diversity of 
the recipient community potentially increases the degree of niche overlap and the likelihood of natural enemy presence; this would in theory increase both the likelihood of competitive exclusion and population regulation of the invader by natural enemies (i.e., the Biotic Resistance Hypothesis; Levine \& D'Antonio 1999). This mechanism predicts that tropical systems harboring a high diversity should therefore be more resistant to invasion. However, results from tropical studies show both positive and negative diversity-invadedness relationships (Ackerman et al. 2017; Denslow et al. 2009; Kueffer et al. 2010; Lannes et al. 2020), in line with what is seen in temperate regions, and this variation is attributable to the multitude of factors that determine both native and non-native diversities, including the scale of study and even statistical artifacts (Fridley et al. 2007). The probability that there is a producer, prey, or host that can interact with a non-native consumer or a suitable mutualistic partner increases with diversity, but the probability of encountering this suitable resource or mutualist decreases (Guo et al. 2019).

The degree of saturation and packing of niche space is a more accurate and direct reflection of biotic resistance than is species diversity or richness (Guo et al. 2015). It is wellestablished that tropical islands — particularly those that are more isolated — are more invaded than are the continental tropics (Denslow et al. 2009; Kueffer et al. 2010; Moser et al. 2018). It has been hypothesized that the reduced size of the species pool of natural colonizers in island ecosystems may have led to more vacant niches and lower overall natural enemy presence, which would benefit newly arriving invasive species (Denslow 2003; Denslow \& DeWalt 2008). It is less clear, however, whether niche space is more saturated in tropical versus temperate continental systems. In addition, if potential niche space is more highly packed in the continental tropics, this would suggest that biotic interactions could be stronger and/or more specialized (MacArthur 1965). If exploitative biotic interactions (e.g., herbivory, predation, parasitism, etc.) are more specialized in the tropics, then a consumer 
species is less likely to be able to find prey or host resources when introduced in the tropics outside of its native range — although they would also be less likely to encounter natural enemies, having left them behind in their native range (Shea \& Chesson 2002). Likewise, if mutualisms involving native species are both more important and more specialized in the tropics, then this could explain the lower establishment success of non-native species. However, evidence for latitudinal gradients in biotic interactions has been mixed, is highly context-dependent, and is the subject of ongoing debate (e.g., Moles \& Ollerton 2016; Schemske et al. 2009).

Fungal pathogens and mycorrhizae form particularly strong associations with plants in the continental tropics (Bagchi et al. 2014; Delavaux et al. 2019), and there is evidence of higher endemism of soil fungal communities in tropical than in temperate regions (Tedersoo et al. 2014). This difference could contribute to either reduced establishment success of nonnative plants through lack of mutualists or increased likelihood of escape of these plants from natural enemies. Further, on average, woody plants are associated more with arbuscular mycorrhizal (AM) fungi in the tropics where they help plants to scavenge for phosphorous, relative to temperate regions where they are associated more with ectomycorrhizal (EM) fungi (Soudzilovskaia et al. 2019; Steidinger et al. 2019), although there are exceptions, such as the tropical forests of Southeast Asia, which are dominated by EM-associated trees of the Dipterocarpaceae. Arbuscular mycorrhizal fungi are less specialized and their interaction networks are more nested, with a few generalist species that associate with most of the plants in the community (van der Heijden et al. 2015), and AM-dominant forests are known to be generally more invasible than ectomycorrhizal-dominant forests (Jo et al. 2018). This suggests that, all else being equal, tropical forest plant-fungal networks should, on average, be more - rather than less - susceptible to plant invasions than are temperate ones. Finally, the proportion of native mycorrhizal plants is lower on islands than on mainland ecosystems, 
while the reverse is true for the proportion of naturalized mycorrhizal plants (Delavaux et al. 2019). This difference suggests that non-native plants on tropical islands may be advantaged relative to natives at least in part from the co-introduction of mycorrhizal mutualists that the native plants cannot utilize (Delavaux et al. 2019).

\subsection{Non-equilibrium Versus Equilibrium Mechanisms}

Resource competition- or consumption-based explanations of low invasibility assume that recipient communities are at or near equilibrium. Further, most discussions of the invasibility of the tropics fail to consider the role of non-equilibrium processes, such as disturbance regimes and dispersal limitation. Rejmánek (1996) suggested that the rapid progression of succession of tropical forests after disturbances would restore equilibrium and competitively exclude non-natives. However, Huston (1994) proposed that the rate of competitive displacement in tropical forests is slow relative to the rate of return of disturbances, therefore allowing maintenance of high species diversity despite limited resource conditions. In the same way, a non-native species should still be able to establish whenever environmental conditions are suitable, at least ephemerally. For example, a pulsed increase of both light and nutrients might occur in tropical forest canopy gaps as a result of the decomposition of dead plant material. In such conditions, non-native species that are inferior resource competitors may establish viable populations if they have superior colonization abilities (Shea \& Chesson 2002). Tropical storms can disperse seeds or spores and accelerate growth and recruitment rates of non-native plants (Murphy \& Metcalfe 2016), implying that ecosystems that are more frequently disturbed by such events are likely to be more invasible.

Both equilibrium and non-equilibrium mechanisms of invasibility predict that tropical ecosystems will be increasingly invaded as they become more disturbed, either directly by human activities or indirectly from more frequent or intense storm or fire events resulting 
from anthropogenically induced climate change. Disturbances may eliminate competitors and expose suitable microsites to establishment of non-native species. Some tropical ecosystems are pre-adapted to specific disturbances that promote potential invaders, while conversely species native to other comparable tropical ecosystems may not be able to adapt when introduced. For example, African savannas have a longer history of association with human disturbances, large herbivores, and fire, which may be the reason for their apparently lower invasibility compared to other tropical savannas (Foxcroft et al. 2010). Other types of ecosystems may be more sensitive to disturbances. For example, in tropical forests, selective logging has often led to increased non-native plant richness and abundances (Brown \& Gurevitch 2004; Döbert et al. 2018; Waddell et al. 2020a). Further, logging roads transport propagules closer to potential sites of invasion (Veldman \& Putz 2010; Veldman et al. 2009), and fragmentation of tropical forests for agriculture exposes forest interiors to higher nonnative propagule pressure (Waddell et al. 2020a). There can also be synergies between different disturbances, such as logging promoting the invasion of grasses which, in turn, increases fuel load and the frequency and intensity of fires (Veldman et al. 2009). While it is still unclear if intact tropical ecosystems have intrinsically low invasibility, there are now many examples of disturbed tropical ecosystems that have been invaded.

\section{CHARACTERISTICS OF INVADERS IN THE TROPICS}

\subsection{Characteristics of invasive plants}

While the various hypotheses on invasibility of tropical relative to temperate regions are based on habitat differences, we might also expect the traits of invasive species to differ between temperate and tropical ecosystems (Pyšek \& Richardson 2006). Many of the most successful invasive plant species in tropical environments are fast-growing, disturbanceadapted pioneer species, much like successful invaders in temperate regions. Important 
insights into traits of tropical invaders come from tropical grasslands and savannas. For example, in the Neotropics many $\mathrm{C} 4$ grass species that have been introduced from Africa for cattle grazing have characteristics that make them ideal for forage (such as high growth rates), but also operate as successful invaders (Foxcroft et al. 2010). Taylor et al. (2018) surveyed traits of invasive plants in tropical savannas in Australia and, similar to what has been shown in temperate areas, found that invaders generally occupied the 'fast' end of the leaf-economic spectrum (i.e., high specific leaf area and leaf nutrient content) relative to the dominant native species. In addition, a meta-analysis of a global traits data set found that the differences in growth rate and physiology between co-occurring invasive and non-invasive species were significantly larger in tropical climates than in temperate climates (van Kleunen et al. 2010). This finding may be attributable to tropical environments selecting for more specific physiological characteristics relative to temperate environments (van Kleunen et al. 2010), or reflective of past human choices in what types of species they introduced into tropical versus temperate ecosystems (van Kleunen et al. 2020). It therefore appears that similar characteristics promote invasions in tropical and temperate areas, but in the tropics these attributes may be more important in separating successful from unsuccessful invaders.

Several plant invasion pathways linked to plant traits have been identified for tropical regions. For example, more tropical naturalized grasses originate from Africa and Asia than from South America (Monnet et al. 2020). This disparity may reflect differences in the characteristics and therefore invasion potential of Old World versus New World grasses, or it could simply arise from the historical movement of people and plants from the Old to the New World. Further, van Kleunen et al. (2020) found an overrepresentation of non-native plant species that have an economic use in the tropics compared to higher latitudes. Among the reported characteristics linked to species having economic value are high growth rates (for plants used for forage, fiber, and biofuels) and resistance to a wide variety of adverse 
environmental conditions (for plants used to control soil erosion or for restoration). As an example, in forestry, several species of non- native trees have been introduced from the Northern Hemisphere tropics to the Southern Hemisphere tropics because of their high growth rates, low numbers of pathogens, and fiber characteristics; several of these species have become invasive (Nuñez et al. 2017). More generally, differences exist in trade between the different regions of the world that can affect our understanding of invasions (Nuñez \& Pauchard 2010), as discussed in Section 5. These differences could potentially confound comparisons of the key charateristics of non-native species among different regions, and it is possible that differences in invasion between tropical and temperate regions could simply be due to differences in propagule pressure irrespective of species traits.

As discussed above, tropical forests are experiencing increasing disturbance, fragmentation, and exposure to non-native propagules. Initially, these increases would favor non-native plant species able to disperse and establish at least into forest edges, and in some cases into canopy gaps far from the points of introduction (Waddell et al. 2020a,b). Dawson et al. (2009) showed that non-native woody plant species in Tanzania were more likely to infiltrate neighboring forests if they could be dispersed over long distances by wind, birds, or primates. For example, two of the most widespread invaders in the tropics, Miconia crenata (formerly Clidemia hirta) and Lantana camara (Figure 3a-b), are dispersed by frugivores (DeWalt \& Hamrick 2004; Ramaswami et al. 2016). In line with this fact, Waddell et al. (2020b) showed that successful invasion of tropical forests requires adaptations for longdistance dispersal (e.g., by vertebrates) as well as traits related to competitive ability, such as being tall and woody. Thus, for disturbed tropical forests at least, evidence points towards the role of plant-dispersal mutualisms as agents for widespread distributions of non-native plants in forests. For both temperate and tropical forests, shade-tolerant non-native species are less frequent than shade intolerant non-native species, but it has been suggested that this 
difference is partially due to historically low introduction effort for such species (Martin et al. 2009). Thus, when propagule pressure is sufficient, invaders may include species with atypical shade-tolerance traits that permit establishment in a low-light forest environment (Dawson et al. 2011; Martin et al. 2009).

Seed bank formation can be also an important characteristic of invasive species in both tropical and temperate areas. Luo et al. (2017) examined forest soil seed banks along an elevational gradient in Yunnan Province, China, and found 15 non-native herbaceous species that accounted for $30 \%$ of the seeds germinated from the tropical site, and four such species at a subtropical site, including Ageratina adenophora. While this latter species was present in the seed bank but not in the understory, it would likely proliferate whenever canopy disturbance allows more sunlight to reach the forest floor. Further, Drake (1998) showed that $67 \%$ of the seeds in Hawaiian dry forest seed banks were non-native, although native seeds plants comprised $95 \%$ of seed-bearing plants in the living vegetation. However, it is not yet clear if this seed-banking characteristic is more or less important in the tropics, and there are also many examples for temperate areas where invasive species have large seed banks (e.g., Eschtruth \& Battles 2009).

With regards to belowground plant traits, allelopathy and nitrogen fixation have been frequently invoked to explain the success of invasive species common in the tropics. Allelopathy has been shown to be a common trait of some important tropical invaders, such as L. camara (Kohli et al. 2006; Singh et al. 2014), though its role in temperate versus tropical invasions remains an open question. Further, and similar to temperate regions, the ability to fix nitrogen symbiotically is a common characteristic of tropical invasive species, particularly on islands where such species can rapidly spread and transform ecosystems (Vitousek \& Walker 1989). However, while the Fabaceae — which contains the vast majority of plants that form nitrogen-fixing symbioses — includes many species that are invasive in 
the tropics, a large number of invasive tropical Fabaceae do not actually form symbioses (Simonsen et al 2007). Introduction biases of fewer tropical N-fixing plant species than in temperate areas could play a role in this pattern, but environmental conditions in the tropics, such as lower availability of phosphorus relative to nitrogen (Du et al. 2020), could also be important particularly for continental ecosystems.

Specific ecosystems require traits that match those ecosystems. For example, some arid and semi-arid grasslands of eastern Africa are especially prone to invasion by trees and shrubs or succulents that are adapted to low rainfall, including mesquite (Prosopis spp.), a phreatophyte with a deep rooting system well suited to low water availability (Abd Elbasit et al. 2012), and prickly pear cacti (Opuntia spp.), which have a photosynthetic system that reduces loss of water through transpiration while maintaining carbon gain (Witt et al. 2018). As another example, the vast majority of plant species that have invaded mangrove forests (most of which are in the tropics) have traits that confer tolerance to high salinity and anaerobic conditions, as well as high fecundity and rapid growth (Biswas et al. 2018).

\subsection{Characteristics of invasive animals}

Less information exists on the traits of invasive animals than for plants in tropical ecosystems. For ants, probably over 600 species have established populations outside their native distributions (Miravete et al. 2014; Suarez et al. 2009), several of which have invaded tropical regions. These include some, such as the Argentine ant (Linepithema humile) and red imported fire ant (Solenopsis invicta), which have invaded both tropical and non-tropical ecosystems, and others, such as the yellow crazy ant (Anoplolepis gracilipes; Figure 3c) and the little fire ant (Wasmannia auropunctata; Figure 3d), which have mostly invaded tropical regions (Bertelsmeier et al. 2016). A recent study focusing on ecological traits of invasive ants found that traits linked to invasiveness included an affinity for disturbed environments, 
the ability to form supercolonies, having a generalist nesting type, and being able to expand through founding independent colonies (Fournier et al. 2019). However, these traits are important for both temperate and tropical environments, and no traits were identified that would be expected to differ inherently between tropical and temperate environments. Further, invasions of mosquitoes involved in human diseases, such as the Asian tiger mosquito (Aedes albopictus), the common malaria mosquito (Anopheles quadrimaculatus), and the yellow fever mosquito (Aedes aegypti), have been explained mainly by climate matching with their native ranges and not by any specific trait that could explain their spread (Cunze et al. 2018; Lounibos 2002).

Several invasive animal species have traits associated with economic use. For example, the honeybee (Apis mellifera) has been introduced to many parts of the world where it has been a successful invader (De Jong 1996). The hybridization of honeybees of European and African origins has conferred traits on this species that promote its success as an invader in the tropics versus in temperate areas. Harrison et al. (2006) found that a key trait favoring the spread of the Africanized hybrid honeybees in the tropics was its high preference for pollen over nectar, which promoted colony growth at the expense of storage of honey for overwintering. For reptiles, good predictors of invasion success in tropical environments include high reproductive rates (such as large and frequent clutches), numbers of introductions (which are often linked to the pet trade), and climate matching with their native range (Bomford et al. 2009; Capinha et al. 2017; Fujisaki et al. 2010). However, it is not clear if these traits confer differences in invasion between tropical and temperate environments.

Even though mammals are among the most impactful invasive species in both tropical and temperate environments, and especially on islands (Courchamp et al. 2003), there is no evidence of differences in specific traits that predict successful invasions between tropical and temperate regions. For birds, studies within three highly invaded regions - Hawaii in the 
tropics, Florida in the subtropics, and temperate New Zealand - found that non-native species closely related to native species had a consistent advantage in terms of establishment and spread, suggesting that similarities in traits between invasive and local species can be important in both tropical and temperate regions (Maitner et al. 2012). Overall, it appears that there are many traits that explain invasion of animal species in both temperate and tropical areas, but some specific traits related to adaptation to warmer areas may give some nonnatives an advantage in the tropics.

\section{IMPACTS OF INVADERS IN TROPICAL ECOSYSTEMS}

Non-native species impact a variety of community and ecosystem properties, including abundance and diversity of native species, food web structure, pollinator and frugivore networks, seed dispersal, ecosystem production, decomposition, nutrient cycling, and geomorphology (Andreu \& Vilà 2011; Fei et al. 2014; Pyšek et al. 2012). For non-native species to exert important effects, not only must they reach sufficient biomass within their trophic level, but they must also have traits that differ from native species already present, and those traits must be ecologically important (Wardle et al. 2011). For plant communities, several syntheses and meta-analyses have provided evidence that trait differences between non-native and native species suffice on average for non-native species to promote plant productivity, soil microbial activity, litter decomposition, nutrient fluxes, and biogeomorphic processes (Fei et al. 2014; Liao et al. 2008; Vilà et al. 2011), although the effects are sometimes weak and are strongly determined by environmental context (Ricciardi et al. 2021). Meanwhile, for invasive animals, despite many examples of their strong impacts in a variety of ecosystems, there have been few serious attempts to develop general predictive principles about their effects (Wardle et al. 2011) except perhaps for their involvement in networks (e.g., Fricke \& Svenning 2020). Syntheses, analyses, and reviews aimed at 
developing principles about the ecological impacts of non-native species have been largely or exclusively dominated by temperate studies, with the exception of some tropical island studies, notably from Hawaii. Because invader effects are driven by environmental context (Ricciardi et al. 2021), and this context differs greatly between tropical and temperate regions, it is unclear if our understanding of invasive species impacts from temperate systems can be meaningfully applied to the tropics (Bellard \& Jeschke 2016).

\subsection{Impacts in the Continental Tropics}

For the lowland continental tropics, several examples point to large impacts of non-native plant species in open-canopy systems, though not in closed-canopy primary forest. Just as in temperate systems, several examples exist of highly successful invasive woody species developing monospecific stands that displace native vegetation in tropical heath and secondary rainforest (e.g., Southeast Asia; Peh 2010) and savanna and woodland (e.g., east Africa; Witt et al. 2018), with several of them involving Acacia species capable of nitrogen fixation (Peh 2010; Witt et al. 2018). Further, parts of the hyperdiverse cerrado ecosystem of Brazil are being transformed by invasive grasses (Figure 3f-g) (Damasceno et al. 2018) and the formation of monospecific stands of the non-native Pinus elliotii (Brewer et al. 2018). There are also a handful of studies of the impacts of invasive animals in both open-canopy and closed-canopy tropical ecosystems. Some examples include the alteration of detrital and herbivore food webs by invasion of the little fire ant (W. auropunctata) in rainforest in west Africa (Dunham \& Mikheyev 2010), damage to tree seedlings, plant litter, and earthworms by invasive wild pigs (Sus scrofa; Figure 3e) in rainforest in tropical Queensland (Mitchell et al. 2007), and changes to native bird communities, seed dispersal, and pollination caused by invasive bird species in forest in southeast Asia (Corlett et al. 2020). 
Currently studies are insufficient to determine quantitatively if invasive species have effects in the lowland continental tropics that differ from those in corresponding temperate systems, but factors that differ overall between the two systems provide scope for differences in impacts to occur (Bellard \& Jeschke 2016). For example, warmer conditions in the tropics might be more conducive to rapid growth that could disproportionately favor non-native plant species and thereby exacerbate their impacts (van Kleunen et al. 2010). Further, the greater domination of tropical forests by AM-associated species may make them more invasible as discussed above, which would in turn lead to greater impacts of non-native species. Conversely, the lower availability of rock-derived nutrients (notably phosphorus) on average in the tropics (Du et al. 2020) could make some regions less conducive to domination by faster-growing and nutrient-demanding invasive plant species and thus minimize their impacts. Further, as mentioned above, non-native legumes in the tropics are less likely to associate with rhizobial symbionts on average than legumes in temperate regions, which will in turn reduce their capacity to transform ecosystems through nitrogen inputs (Simonsen et al. 2017). Finally, at least for closed-canopy tropical rainforests, the low levels of light transmission through the canopy could exclude invasive plants and therefore reduce their impacts more in tropical than temperate forests (Fine 2002). We emphasize that these factors apply largely to plants; developing predictions of how impacts of invasive animals may respond to differences between temperate and tropical environments poses greater challenges.

\subsection{Impacts on Tropical Oceanic Islands}

The relative simplicity of oceanic island communities leads not only to greater invasibility, but also to greater impacts, compared with the mainland (Pyšek et al. 2012; Simberloff 1995). There are numerous examples of invasive plants transforming tropical oceanic island ecosystems, with a disproportionate number from the Hawaiian archipelago. Several 
examples involve invasive nitrogen-fixing plants, including classic studies (e.g., Vitousek \& Walker 1989) pointing to transformation of several community and ecosystem properties following invasion of intact forest by the shrub Morella faya. Others point to domination of the forest understory by invasive grasses that alter biogeochemical processes and prevent tree seedling regeneration (Litton et al. 2006). Frequently, multiple invasive species are involved following grass invasion, with initial invaders facilitating establishment of secondary invaders at the expense of the native plant community (D'Antonio et al. 2017).

There are also several examples of far-reaching effects of invasion of tropical oceanic islands by animal species. Many islands throughout the tropics and elsewhere are invaded by predatory and omnivorous vertebrates (e.g., cats, rats, dogs, mongoose, wild pigs) that impact native prey species, and therefore the ecosystem functions that prey species carry out. For example, invasion of the Chagos Islands by rats has eliminated populations of seabirds that transport nutrients from the ocean to land, impairing nutrient fluxes and halting nutrient runoff to nearby coral communities (Graham et al. 2018). Further, the invasive brown tree snake Boiga irregularis in Guam (Figure 3h) has greatly impaired tree seedling reproduction and recruitment indirectly by eliminating frugivores and disrupting fruit-frugivore mutualisms (Rogers et al. 2017). The invasive bulbul Pycnonotus jocosus in Mauritius has contributed to declines of native bird and spider species and the spread of non-native plant species (Linnebjerg et al. 2010). Invasive invertebrates can also have far-ranging impacts. For example, invasive snails have caused losses of many endemic snail species throughout the Pacific through both competition and predation (Davis-Berg 2012). Further, the yellow crazy ant (A. gracilipes) on Christmas Island devours and halts activity by red land crabs that are the major agent of litter fragmentation and selective tree seedling recruitment (O'Dowd et al. 2003). However, while many examples exist of the considerable effects of invasive species on tropical islands, we are not yet in a position to determine if differences in environmental 
factors between tropical and temperate islands (e.g., climate) cause the effects of invasive species to be somehow stronger on tropical islands.

\subsection{Tropical versus Temperate Impacts}

Some of the biggest differences in invader impacts between tropical and other regions are likely to involve major functional groups of biota that are concentrated in the tropics, and there are two prominent examples. First, $\mathrm{C} 4$ grasses, which are confined to warmer regions of the globe, are fast growing and rapidly produce large quantities of flammable aboveground material. Therefore, in many drier tropical regions in Brazil, northern Australia, and Hawaii, invasion of $\mathrm{C} 4$ grasses into woody vegetation promotes fire-load, leading to a grass-fire cycle and possible eventual and irreversible conversion into grasslands (D'Antonio et al. 2011; Silvério et al. 2013) that have fundamental differences in their nutrient cycling (Mack et al. 2001). Second, mangrove ecosystems, which are mainly dominant in tropical coastal environments, have a key role in land stabilization, carbon sequestration, and habitat provision for other biota. Invasion of mudflats by mangrove species on remote islands that lack native mangroves thus leads to large increases in the coastal storage of 'blue' carbon (Davidson et al. 2018). Further, there are several examples throughout the tropics of invasion of native mangrove ecosystems by other salt-tolerant plant species, causing changes in coastal hydrology through sediment trapping, conversion to marshes, alteration of soil fertility and water tables, impairment of mangrove seedling regeneration, and loss of habitat for associated animal communities (Biswas et al. 2018).

The relative dearth of studies that have explored impacts of invasive species in the tropics, particularly in continental regions, creates challenges in providing meaningful insights about the extent to which invasions are contributing to the anthropogenic transformation of tropical landscapes. The need is for both manipulative (e.g., invader 
removal) experiments (D'Antonio et al. 2017) and 'natural experiments' (e.g., Graham et al. 2018) for assessing how invasive species impact tropical ecosystems independently of covarying and confounding factors. There is also considerable scope for 'distributed experiments' to assess invader impacts simultaneously in temperate and tropical regions, and for focusing on the impacts of invader groups that are widely distributed in both regions, such as rats, wild pigs, and plant genera such as Acacia and Pinus. Further, we have almost no information from the tropics on impacts for many important groups of organisms or types of ecosystems. Most studies in the tropics have focused on invasive plants, vertebrates, and ants, and we have minimal knowledge of impacts of invasive soil invertebrates or microbes despite their role in driving decomposition, biogeochemical fluxes, nutrient supply, and ultimately primary productivity. We also have little knowledge about invader impacts on high-elevation ecosystems on tropical mountains that are often colonized by non-native temperate grasses and forbs. Finally, it is essential to remember that biotas are being transformed not only by gains of non-native species but also losses of native species; in tropical systems as elsewhere, it remains an open question as to how landscapes are being affected by losses of some species and their replacement by new species that could potentially play a fundamentally different ecological role (Wardle et al. 2011).

\section{RESPONDING OR ADAPTING TO BIOLOGICAL INVASIONS IN THE}

\section{TROPICS}

Until recently, differences in environmental management between the tropical and temperate parts of the world largely coincided with variation in economic development, but this correlation has been considerably weakened in the last 20 years by rapid development in many tropical countries. Although most World Bank low-income countries are still in the tropics, most tropical countries are now in the middle-income categories, and there are 
several small high-income countries, as well as Hawaii, several French overseas territories, and the tropical region of Australia. National gross domestic product values tend to be closely related to factors influencing the strength of invasion pathways, such as maritime shipping traffic and international travel (Sardain et al. 2019), and with the scientific, technical, and financial capacity for response. However, time lags (> 50 years in some cases; Essl et al. 2011) between first introduction and establishment in the wild mean that large invasion debts may be present in tropical countries that have been transformed economically over this period.

\subsection{Tropical Trade}

Global shipping traffic grew fourfold between 1992 and 2012 and is projected to increase by between $240 \%$ and $1209 \%$ by 2050 , depending on country, with much of this growth in current middle-income countries (Sardain et al. 2019). A priori, tropical invasions are most likely to result from direct tropical-tropical connections, but no such major shipping routes link geographically distant tropical regions and there are few direct flights. China's ambitious Belt \& Road Initiative is, however, an additional risk factor for tropical invasions, since much of the associated trade will flow through tropical and subtropical ports in China (Liu et al. 2019). Also, some tropical airports now handle huge numbers of incoming tourists from all over the world, and passenger luggage is a source of invasive arthropods (Liebhold et al. 2006) and other organisms. Additional risk comes from the poorly documented domestic trade within large tropical countries, like Indonesia, which incorporate more than one biogeographic region.

Most invasive species are introduced through a small subset of global trade activities (pets, forestry, horticulture etc.) that are not necessarily correlated with total trade. Pet lovers and gardeners often seek out rare exotic pets and plants even though they are known risk 
agents (Lockwood et al. 2019). There has been explosive growth in such practices with rising incomes in tropical countries, and this growth has elevated the rates of introduction of invasive plants, plant pests, and non-native vertebrates (Corlett et al. 2020; Liu et al. 2020). In Indonesia, the vast internal pet trade has moved many vertebrate species across Wallace's Line, some of which have then become invasive (Corlett et al. 2020), and there are similar problems in Brazil (Alves et al. 2019). Plantation forestry is also expanding rapidly throughout the tropics. Non-native species are preferentially planted, and the risks of these becoming invasive are rarely considered, despite the massive propagule pressure plantations can exert (Padmanaba \& Corlett 2014).

Promotion of trade and tourism is a common priority for almost all countries and could potentially outweigh actions to prevent, monitor, and manage invasive non-native species. The striking contrast between the layers of passenger-delaying biosecurity that greet international arrivals in Australia and the much lower level of such restrictions on arrival in Hawaii illustrate contrasting approaches to the trade-offs between screening and welcoming tourists. Moreover, there is evidence that biosecurity measures can disproportionately burden developing countries (Murina \& Nicita 2017). Country Reports to the Convention on Biological Diversity (CBD) on progress in achieving Aichi Target 9 (and GSPC Target 10) provide more-or-less standardized information on country plans and priorities. Previous analyses of $4^{\text {th }}$ and $5^{\text {th }}$ National Reports (Early et al. 2016; Latombe et al. 2017) suggest that additional capacity to prevent, monitor, and manage invasive species would benefit many tropical countries. However, the $6^{\text {th }}(2019)$ National Reports (www.cbd.int/nr6/) show greater recent progress in many tropical countries, including major biodiversity hotspots (e.g., Brazil, Indonesia, Kenya, Thailand). This change demonstrates that an increasing level of awareness of the issue in national governments can facilitate progress towards implementing the targets. There are also programs, such as Implementation \& Capacity Development of the 
International Plant Protection Convention (www.ippc.int/en/core-activities/capacitydevelopment/) and the CABI Sanitary and Phytosanitary Capacity Development Program (Day 2013), that facilitate cooperation by economically developed countries to promote phytosanitary capacity-building in developing countries.

\subsection{Responding to the Threat of Invasions}

Global research and development funding and expenditure is overwhelmingly concentrated in temperate regions (Figure 1c). Among tropical countries, only India and Brazil are in the global top 10 in terms of domestic expenditure on R\&D, and only Brazil, Malaysia, Singapore, and Thailand spend at least $1 \%$ of GDP on R\&D, as do part-tropical China and Australia. An unknown but undoubtedly small proportion of this expenditure is allocated toward research on invasive species. The USA, France, UK, Japan, China, Germany, and several additional countries in Europe conduct long-term ecological research with collaborators in the tropics, partly in their overseas territories for the first three. Limited research funding is reflected in tropical underrepresentation in the international invasive species literature, with the majority of publications in peer-reviewed journals led by research groups from Australia, China, the USA, Europe, Mexico, Brazil, and India (Figure 1b). This underrepresentation does not necessarily reflect a low priority for such research in the tropics, however. Searches of local journals and national publication databases across the tropics suggest that projects on invasive species are frequently given to undergraduate and graduate students or are carried out by local university researchers and protected-area staff. The results of some of this work are available in local journals and government publications, but often not in English (e.g., in Indonesian, Thai, Spanish, and Brazilian Portuguese). Most publications are descriptive and many are species lists or new invasive records, although some also report control efforts (e.g., Sitepu 2020). 
The use of cost-benefit analyses to prioritize management efforts is rarely reported in the tropics (Povak et al. 2017), although inadequate funding is often mentioned as a constraint on active management in both tropical and non-tropical countries. Prevention makes economic sense everywhere, and monitoring of non-native species is not expensive where the taxonomic capacity exists (Latombe et al. 2017), as it does in many tropical countries. However, effective management or control measures can be costly. Attempts at control of invasive plants in tropical countries have largely been through cutting, manual weeding, fire, or herbicide application (Assis et al. 2020; Padmanaba et al. 2017), drawing on the low labor costs in many developing countries (Nuñez \& Pauchard 2010). Despite some spectacular successes with classical biological control of crop pests in tropical countries (Wyckhuys et al. 2020), the systematic application of this control method in the tropics to invasive species in non-agricultural systems is still mostly confined to Australia (Australian Department of Agriculture 2020) and Hawaii (Pejchar et al. 2020). There have also been important successes with eradication of mammals (Russell \& Holmes 2015) and insect pests (Vreysen et al. 2000) from tropical islands, but these have largely been carried out by, or in collaboration with, non-tropical governments and NGOs. Attempts at local eradication of invasive ants in the tropics — often unsuccessful — have also been done largely in tropical Australia and Hawaii, with a few on other tropical islands (Hoffmann et al. 2016). Funding also appears to limit the widespread use of costly fencing to exclude vertebrate invasions (Pejchar et al. 2020).

One striking, but poorly documented, tropical-temperate difference is in adaptation to and use of invasive species. Tebboth et al. (2020) focus on the invasive shrub Prosopis juliflora in Ethiopia, but their finding that perceptions of this species range from 'menace' to 'resource', could also be applied to many other invasive plants and animals in the rural tropics, where a utilitarian attitude to the flora and fauna, native or not, overrides other 
considerations. Further, the Neotropical shrub Chromolaena odorata is widely used in both West Africa and tropical Asia, often for medicinal purposes (Aigbedion-Atalor 2020; Phumthum et al. 2018). This is not just an issue in developing countries: the attitudes of indigenous people to invasive vertebrates in northern Australia do not align with the native/non-native dichotomy (Robinson et al. 2005), and this deviation is also true of local people - particularly recreational hunters - in the Hawaiian Islands and elsewhere in the Pacific (Lohr et al. 2014). It is probable that few invaders will ever be eradicated after establishment, except on islands, and control efforts are rarely effective in preventing all adverse impacts, so adaptation is as important for invasive species management as it is for climate change (Howard 2019).

Regional coordination and cooperation on invasive species research and action may be necessary to curb invasions in the tropics. The proximity and connectedness of regional neighbors argues for sharing information and experiences, and a common regional policy on prevention (Soliman et al. 2016). However, although regional cooperation on other environmental issues is common in Southeast Asia, East Africa, and the Neotropics, the National Reports to the CBD suggest that each tropical country tackles invasive species largely in isolation, relying on global resources, such as the Global Invasive Species Database (http://www.iucngisd.org/gisd/), rather than on neighbors' collective experience.

\section{CONCLUSIONS: GOING FORWARD}

There are far fewer documented examples of biological invasions in tropical than in temperate regions, which could be due either to less research on tropical invasions, or to tropical systems being less invaded. In this review, we have highlighted many recent studies and examples of invasions recorded from the tropics; most of this research has been on plants, with fewer (and largely iconic) examples for animals that are concentrated on oceanic 
islands, and almost nothing on microorganisms. For plants, differences in invasions between tropical and temperate regions might be due in part to light as a limiting resource, at least in rainforest, but the lower availability of soil phosphorous on average in the tropics (though with several exceptions) may also serve as a partial explanation, at least for continental land masses. Interactions of invasive plants with other biota could also play a role, for example through differences in mycorrhizal associations and the importance of dispersal mutualisms in tropical versus temperate ecosystems. For animals, there are currently too few studies to allow us to develop clear principles about whether and how their invasions differ between tropical and temperate systems, and this is an area in definite need of further work.

Apart from the limited patterns above, there is little compelling or consistent evidence for large differences between tropical and temperate ecosystems in terms of their inherent invasibility. Some differences between tropical and temperate invaders have been documented in the types of traits that lead to their success and the way that they impact invaded ecosystems, but the importance or consistency of these differences is far from clear. Comparisons of invasions in tropical versus temperate regions require careful separation of purely ecological mechanisms from those relating to introduction effort and history. Any barriers to invasions in tropical natural areas can often be overcome with increasing disturbance and availability of propagules, and these two factors are tightly linked. Invaders of tropical savannas appear to be mostly grasses from Africa, while some of the most important tropical ant invaders are from floodplains of South America. Both patterns suggest that pre-adaptations to disturbance regimes in native ranges may assist their invasions into human-disturbed areas elsewhere. Impacts of tropical invasions may be limited in a large part by barriers to establishment; once disturbances and propagule pressure are sufficient to overcome barriers to establishment, spread and impact of invasive species will correspondingly increase. Thus, it may be that invasions in tropical ecosystems are at least 
initially the passengers of change from disturbances, as is often the case in temperate systems. However, positive feedback loops between invasions and disturbances may eventually result in displacement of natives and dominance by non-native species; this outcome is already apparent where disturbed tropical ecosystems are invaded by $\mathrm{C} 4$ grass species that promote a fire cycle.

Greater recent international mobility and the growing scale of regional trade agreements, infrastructure projects, and investments have already put tremendous pressure on tropical ecosystems in terms of land-use change and overexploitation. For this reason, we expect that pressures from biological invasions are already underway. While trade protectionism and the impact of the current coronavirus disease pandemic may have caused a slow-down or a pause in movement of people and goods, or even increased investment in biosecurity, any such impediment is only temporary. As current development in tropical countries tracks that of temperate economies, the state of the environment may converge towards the same eventual outcome: ecosystems that are increasingly fragmented, degraded, and composed of non-native species. There is still a window of opportunity to avoid this future in the tropics.

\section{SUMMARY POINTS}

1. The vast majority of the international biological invasion literature is from temperate regions, with minimal contribution from the tropics, except from some island systems.

2. There are now many examples of the establishment and spread of non-native plant and animal species in the tropics, mostly in disturbed areas. Some cases of ecological impacts have also been demonstrated in the tropics. 
3. Nonetheless, well-studied tropical cases of successful invaders and their impacts are still too few and too concentrated on oceanic islands to allow many general conclusions, especially for animals.

4. There is some, but relatively weak, evidence that tropical and temperate regions differ ecologically in terms of invasibility, or that tropical and temperate invaders differ in the biological traits that determine their success or their impacts.

5. Successful establishment in tropical natural areas correlates with increasing disturbance — in line with expectations from both equilibrium and non-equilibrium theories of invasibility — as well as increasing propagule pressure, just as it does in temperate regions.

6. The rising numbers of documented invasions and impacts in the tropics are a harbinger of the 'calling-in' of invasion debt in tropical countries from recent economic development and trade and income growth.

7. There is increasing awareness of the threat of biological invasions in tropical countries, but there is a general under-investment in scientific and management capacities, and also in regional coordination, to document and respond to this growing threat.

\section{FUTURE ISSUES}

1. Recent syntheses, reviews and meta-analyses that underpin current theory for invasion biology draw mainly from literature from temperate regions, except for a few oceanic island systems such as Hawaii, and there is a need to understand better the extent to which this theory also applies to the tropics.

2. The mechanisms by which plant invasibility differs between tropical and temperate regions need further investigation. These include the roles of limitation by resources 
(e.g., light, soil phosphorous) and of biotic interactions, including those with soil biota and root symbionts.

3. More studies of the impacts of invading species, especially animals, in the continental tropics are required. These need to go beyond description and observations to experiments (both manipulative and opportunistic), potentially including distributed experiments to test hypotheses and quantify impacts on a pantropical or global scale.

4. There is a need to understand and predict how ongoing environmental changes resulting from human activity, such as land use, pollution and climate change, will influence future invasions of the tropics and their impacts.

5. Cost-effectiveness and cost-benefit analysis are needed to inform the prioritization of biosecurity measures and other prevention or control strategies to mitigate the potentially growing impact of biological invasions in tropical countries, while at the same time not over-burdening them with the financial and economic trade-offs.

\section{ACKNOWLEDGMENTS}

This manuscript emerged from a workshop on 'Biological Invasions in the Tropics' through the partnership between Nanyang Technological University (NTU) and the Smithsonian Institution, which was organized by DAW, KYC, MN and KMN, and funded and hosted by NTU. We thank Chua Siew Chin, Adrian Loo, Alex Yee, and Shimona Quazi for participating in the workshop. AML was supported by grant EVA4.0, No.

CZ.02.1.01/0.0/0.0/16_019/0000803 financed by OP RDE. FC is supported by the AXA Research Fund Chair of Invasion Biology of the University Paris Saclay and the AlienScenario project of BiodivERsA and Belmont-Forum call 2018. 


\section{LITERATURE CITED}

Abd Elbasit MAM, Yasuda H, Yoda K, Eldoma AM, Nawata H, et al. 2012. Mesquite (Prosopis spp.) water uptake under different simulated drought conditions. J. Arid L. Stud. 22(1):5-8

Ackerman JD, Tremblay RL, Rojas-Sandoval J, Hernández-Figueroa E. 2017. Biotic resistance in the tropics: patterns of seed plant invasions within an island. Biol. Invasions 19(1):315-28

Aigbedion-Atalor PO. 2020. Weed or not a weed? Density, perceptions and management of Chromolaena odorata (Asteraceae) in West Africa: Voices from Ghana. Weed Res. 60(6):406-14

Alves RRN, de Araújo BMC, da Silva Policarpo I, Pereira HM, Borges AKM, et al. 2019. Keeping reptiles as pets in Brazil: Ethnozoological and conservation aspects. J. Nat. Conserv. 49:9-21

Andreu J, Vilà M. 2011. Native plant community response to alien plant invasion and removal. Manag. Biol. Invasions 2:81-94

Assis GB, Pilon NAL, Siqueira MF, Durigan G. 2020. Effectiveness and costs of invasive species control using different techniques to restore cerrado grasslands. Restor. Ecol. In press

Australian Department of Agriculture. 2020. Revised Guidelines for the Introduction of Exotic Biological Control Agents for the Control of Weeds and Plant Pests. https://www.agriculture.gov.au/biosecurity/risk-analysis/biological-controlagents/protocol_for_biological_control_agents

Barlow J, Gardner TA, Hicks CC, Lennox GD, Berenguer E, et al. 2018. The future of hyperdiverse tropical ecosystems. Nature 559:517-26

Bellard C, Cassey P, Blackburn TM. 2016. Alien species as a driver of recent extinctions. Biol. Lett. 12:20150623

Bellard C, Jeschke JM. 2016. A spatial mismatch between invader impacts and research publications. Conserv. Biol. 30(1):230-32

Bertelsmeier C, Blight O, Courchamp F. 2016. Invasions of ants (Hymenoptera: Formicidae) in light of global climate change. Myrmecological News 22:25-42

Biswas SR, Biswas PL, Limon SH, Yan ER, Xu MS, Khan MSI. 2018. Plant invasion in mangrove forests worldwide. For. Ecol. Manage. 429:480-92

Blackburn TM, Pyšek P, Bacher S, Carlton JT, Duncan RP, et al. 2011. A proposed unified framework for biological invasions. Trends Ecol. Evol. 26(7):333-39

Bomford M, Kraus F, Barry SC, Lawrence E. 2009. Predicting establishment success for alien reptiles and amphibians: A role for climate matching. Biol. Invasions 11(3):713-24

Brewer JS, Souza FM, Callaway RM, Durigan G. 2018. Impact of invasive slash pine (Pinus elliottii) on groundcover vegetation at home and abroad. Biol. Invasions 20(10):2807-20

Brown KA, Gurevitch J. 2004. Long-term impacts of logging on forest diversity in Madagascar. Proc. Natl. Acad. Sci. U. S. A. 101(16):6045-49

Bustamante MMC, de Brito DQ, Kozovits AR, Luedemann G, de Mello TRB, et al. 2012. Effects of nutrient additions on plant biomass and diversity of the herbaceous-subshrub layer of a Brazilian savanna (Cerrado). Plant Ecol. 213(5):795-808

Capinha C, Seebens H, Cassey P, García-Díaz P, Lenzner B, et al. 2017. Diversity, biogeography and the global flows of alien amphibians and reptiles. Divers. Distrib. 23(11):1313-22

Catford JA, Vesk PA, Richardson DM, Pyšek P. 2012. Quantifying levels of biological invasion: towards the objective classification of invaded and invasible ecosystems. Glob. Chang. Biol. 18:44-62 
Corlett RT, Leven MR, Yong DL, Eaton JA, Round PD. 2020. Continental analysis of invasive birds: Asia. In Invasive Birds: Global Trends and Impacts, eds. CT Downs, LA Hart, pp. 314-339. Wallingford, UK: CAB International

Courchamp F, Chapuis JL, Pascal M. 2003. Mammal invaders on islands: Impact, control and control impact. Biol. Rev. Camb. Philos. Soc. 78(3):347-83

Cunze S, Kochmann J, Koch LK, Klimpel S. 2018. Niche conservatism of Aedes albopictus and Aedes aegypti - two mosquito species with different invasion histories. Sci. Rep. 8:7733

D'Antonio CM, Hughes RF, Tunison JT. 2011. Long-term impacts of invasive grasses and subsequent fire in seasonally dry Hawaiian woodlands. Ecol. Appl. 21(5):1617-28

D'Antonio CM, Ostertag R, Cordell S, Yelenik S. 2017. Interactions among invasive plants: Lessons from Hawai' i. Annu. Rev. Ecol. Evol. Syst. 48:521-41

Damasceno G, Souza L, Pivello VR, Gorgone-Barbosa E, Giroldo PZ, Fidelis A. 2018. Impact of invasive grasses on Cerrado under natural regeneration. Biol. Invasions 20(12):3621-29

Davidson IC, Cott GM, Devaney JL, Simkanin C. 2018. Differential effects of biological invasions on coastal blue carbon: A global review and meta-analysis. Glob. Chang. Biol. 24(11):5218-30

Davis-Berg EC. 2012. The predatory snail Euglandina rosea successfully follows mucous trails of both native and non-native prey snails. Invertebr. Biol. 131(1):1-10

Dawson W, Burslem DFRP, Hulme PE. 2009. Factors explaining alien plant invasion success in a tropical ecosystem differ at each stage of invasion. J. Ecol. 97(4):657-65

Dawson W, Burslem DFRP, Hulme PE. 2011. The comparative importance of species traits and introduction characteristics in tropical plant invasions. Divers. Distrib. 17(6):111121

Day RK. 2013. More Trade, Safer Trade: Strengthening Developing Countries' Sanitary and Phytosanitary (SPS) Capacity. CABI Working Paper. 4

De Jong D. 1996. Africanized honey bees in Brazil, forty years of adaptation and success. Bee World 77(2):67-70

Delavaux CS, Weigelt P, Dawson W, Duchicela J, Essl F, et al. 2019. Mycorrhizal fungi influence global plant biogeography. Nat. Ecol. Evol. 3(3):424-29

Denslow JS. 2003. Weeds in paradise: Thoughts on the invasibility of tropical islands. Ann. Missouri Bot. Gard. 90(1):119-27

Denslow JS, DeWalt SJ. 2008. Exotic plant invasions in tropical forests: patterns and hypotheses. In Tropical Forest Community Ecology, eds. WP Carson, SA Schnitzer, pp. 409-26. Wiley-Blackwell

Denslow JS, Space JC, Thomas PA. 2009. Invasive exotic plants in the tropical pacific islands: Patterns of diversity. Biotropica 41(2):162-70

DeWalt SJ, Hamrick JL. 2004. Genetic variation of introduced Hawaiian and native Costa Rican populations of an invasive tropical shrub, Clidemia hirta (Melastomataceae). Am. J. Bot. 91(8):1155-62

Döbert TF, Webber BL, Sugau JB, Dickinson KJM, Didham RK. 2018. Logging, exotic plant invasions, and native plant reassembly in a lowland tropical rain forest. Biotropica 50(2):254-65

Drake DR. 1998. Relationships among the seed rain, seed bank and vegetation of a Hawaiian forest. J. Veg. Sci. 9(1):103-12

Du E, Terrer C, Pellegrini AFA, Ahlström A, van Lissa CJ, et al. 2020. Global patterns of terrestrial nitrogen and phosphorus limitation. Nat. Geosci. 13(3):221-26

Dunham AE, Mikheyev AS. 2010. Influence of an invasive ant on grazing and detrital communities and nutrient fluxes in a tropical forest. Divers. Distrib. 16(1):33-42 
Early R, Bradley BA, Dukes JS, Lawler JJ, Olden JD, et al. 2016. Global threats from invasive alien species in the twenty-first century and national response capacities. Nat. Commun. 7:12485

Eschtruth AK, Battles JJ. 2009. Assessing the relative importance of disturbance, herbivory, diversity, and propagule pressure in exotic plant invasion. Ecol. Monogr. 79(2):265-80

Ess1 F, Dullinger S, Rabitsch W, Hulme PE, Hülber K, et al. 2011. Socioeconomic legacy yields an invasion debt. Proc. Natl. Acad. Sci. U. S. A. 108(1):203-7

Fei S, Phillips J, Shouse M. 2014. Biogeomorphic impacts of invasive species. Annu. Rev. Ecol. Evol. Syst. 45:69-87

Fine PVA. 2002. The invasibility of tropical forests by exotic plants. J. Trop. Ecol. 18:687705

Fournier A, Penone C, Pennino MG, Courchamp F. 2019. Predicting future invaders and future invasions. Proc. Natl. Acad. Sci. U. S. A. 116(16):7905-10

Foxcroft LC, Richardson DM, Rejmánek M, Pyšek P. 2010. Alien plant invasions in tropical and sub-tropical savannas: Patterns, processes and prospects. Biol. Invasions 12(12):3913-33

Fricke EC, Svenning JC. 2020. Accelerating homogenization of the global plant-frugivore meta-network. Nature 585:74-78

Fridley JD, Stachowicz JJ, Naeem S, Sax DF, Seabloom EW, et al. 2007. The invasion paradox: reconciling pattern and process in species invasions. Ecology 88(1):3-17

Fujisaki I, Hart KM, Mazzotti FJ, Rice KG, Snow S, Rochford M. 2010. Risk assessment of potential invasiveness of exotic reptiles imported to South Florida. Biol. Invasions 12(8):2585-96

Gardner TA, Barlow J, Chazdon R, Ewers RM, Harvey CA, et al. 2009. Prospects for tropical forest biodiversity in a human-modified world. Ecol. Lett. 12(6):561-82

Graham NAJ, Wilson SK, Carr P, Hoey AS, Jennings S, MacNeil MA. 2018. Seabirds enhance coral reef productivity and functioning in the absence of invasive rats. Nature 559(7713):250-53

Guo Q, Fei S, Dukes JS, Oswalt CM, Iannone III B V., Potter KM. 2015. A unified approach for quantifying invasibility and degree of invasion. Ecology 96(10):2613-21

Guo Q, Fei S, Potter KM, Liebhold AM, Wen J. 2019. Tree diversity regulates forest pest invasion. Proc. Natl. Acad. Sci. U. S. A. 116(15):7382-86

Harrison JF, Fewell JH, Anderson KE, Loper GM. 2006. Environmental physiology of the invasion of the Americas by Africanized honeybees. Integr. Comp. Biol. 46(6):1110-22

Hoffmann BD, Luque GM, Bellard C, Holmes ND, Donlan CJ. 2016. Improving invasive ant eradication as a conservation tool: A review. Biol. Conserv. 198:37-49

Howard PL. 2019. Human adaptation to invasive species: A conceptual framework based on a case study metasynthesis. Ambio. 48(12):1401-30

Jo I, Potter KM, Domke GM, Fei S. 2018. Dominant forest tree mycorrhizal type mediates understory plant invasions. Ecol. Lett. 21(2):217-24

Kerns BK, Tortorelli C, Day MA, Nietupski T, Barros AMG, et al. 2020. Invasive grasses: A new perfect storm for forested ecosystems? For. Ecol. Manage. 463:117985

Kohli RK, Batish DR, Singh HP, Dogra KS. 2006. Status, invasiveness and environmental threats of three tropical American invasive weeds (Parthenium hysterophorus L., Ageratum conyzoides L., Lantana camara L.) in India. Biol. Invasions 8(7):1501-10

Kueffer C, Daehler CC, Torres-Santana CW, Lavergne C, Meyer JY, et al. 2010. A global comparison of plant invasions on oceanic islands. Perspect. Plant Ecol. Evol. Syst. 12(2):145-61

Lai HR, Tan GSY, Neo L, Kee CY, Yee ATK, et al. 2021. Decoupled responses of native and exotic tree diversities to distance from old-growth forest and soil phosphorous in novel 
secondary forests. Appl. Veg. Sci. 24:e12548

Lannes LS, Bustamante MMC, Edwards PJ, Olde Venterink H. 2012. Alien and endangered plants in the Brazilian Cerrado exhibit contrasting relationships with vegetation biomass and N : P stoichiometry. New Phytol. 196(3):816-23

Lannes LS, Karrer S, Teodoro DAA, Bustamante MMC, Edwards PJ, Olde Venterink H. 2020. Species richness both impedes and promotes alien plant invasions in the Brazilian Cerrado. Sci. Rep. 10(1):1-9

Latombe G, Pyšek P, Jeschke JM, Blackburn TM, Bacher S, et al. 2017. A vision for global monitoring of biological invasions. Biol. Conserv. 213:295-308

Levine JM, D'Antonio CM. 1999. Elton revisited: a review of evidence linking diversity and invasibility. Oikos $87(1): 15-26$

Liao C, Peng R, Luo Y, Zhou X, Wu X, et al. 2008. Altered ecosystem carbon and nitrogen cycles by plant invasion: A meta-analysis. New Phytol. 177(3):706-14

Liebhold AM, Work TT, McCullough DG, Cavey JF. 2006. Airline baggage as a pathway for alien insect species invading the United States. Am. Entomol. 52(1):48-54

Linnebjerg JF, Hansen DM, Bunbury N, Olesen JM. 2010. Diet composition of the invasive red-whiskered bulbul Pycnonotus jocosus in Mauritius. J. Trop. Ecol. 26(3):347-50

Litton CM, Sandquist DR, Cordell S. 2006. Effects of non-native grass invasion on aboveground carbon pools and tree population structure in a tropical dry forest of Hawaii. For. Ecol. Manage. 231:105-13

Liu X, Blackburn TM, Liu X, Blackburn TM, Song T, et al. 2019. Risks of biological invasion on the Belt and Road. Curr. Biol. 29:499-505

Liu X, Blackburn TM, Song T, Wang X, Huang C, Li Y. 2020. Animal invaders threaten protected areas worldwide. Nat. Commun. 11:2892

Lockwood JL, Welbourne DJ, Romagosa CM, Cassey P, Mandrak NE, et al. 2019. When pets become pests: the role of the exotic pet trade in producing invasive vertebrate animals. Front. Ecol. Environ. 17(6):323-30

Lohr CA, Lepczyk CA, Johnson ED. 2014. The islands are different: Human perceptions of game species in Hawaii. Environ. Manage. 54(4):814-27

Lonsdale W. 1999. Global patterns of plant invasions and the concept of invasibility. Ecology 80(5):1522-36

Lounibos LP. 2002. Invasions by insect vectors of human disease. Annu. Rev. Entomol. 47:233-66

Luo X, Cao M, Zhang M, Song X, Li J, et al. 2017. Soil seed banks along elevational gradients in tropical, subtropical and subalpine forests in Yunnan Province, southwest China. Plant Divers. 39(5):273-86

MacArthur RH. 1965. Patterns of species diversity. Biol. Rev. 40:510-33

Mack MC, D'Antonio CM, Ley RE. 2001. Alteration of ecosystem nitrogen dynamics by exotic plants: A case study of C4 grasses in Hawaii. Ecol. Appl. 11(5):1323-35

Maitner BS, Rudgers JA, Dunham AE, Whitney KD. 2012. Patterns of bird invasion are consistent with environmental filtering. Ecography 35(7):614-23

Martin PH, Canham CD, Marks PL. 2009. Why forests appear resistant to exotic plant invasions: intentional introductions, stand dynamics, and the role of shade tolerance. Front. Ecol. Environ. 7(3):142-49

Miravete V, Roura-Pascual N, Dunn RR, Gómez C. 2014. How many and which ant species are being accidentally moved around the world? Biol. Lett. 10:20140518

Mitchell J, Dorney W, Mayer R, McIlroy J. 2007. Spatial and temporal patterns of feral pig diggings in rainforests of north Queensland. Wildl. Res. 34(8):597-602

Moles AT, Ollerton J. 2016. Is the notion that species interactions are stronger and more specialized in the tropics a zombie idea? Biotropica 48(2):141-45 
Monnet AC, Vorontsova MS, Govaerts RHA, Svenning JC, Sandel B. 2020. Historical legacies and ecological determinants of grass naturalizations worldwide. Ecography 43(9):1373-85

Moser D, Lenzner B, Weigelt P, Dawson W, Kreft H, et al. 2018. Remoteness promotes biological invasions on islands worldwide. Proc. Natl. Acad. Sci. U. S. A. 115(37):927075

Murina M, Nicita A. 2017. Trading with conditions: The effect of sanitary and phytosanitary measures on the agricultural exports from low-income countries. World Econ. 40(1): 168-81

Murphy GEP, Romanuk TN. 2014. A meta-analysis of declines in local species richness from human disturbances. Ecol. Evol. 4(1):91-103

Murphy HT, Metcalfe DJ. 2016. The perfect storm: Weed invasion and intense storms in tropical forests. Austral Ecol. 41(8):864-74

Nuñez MA, Chiuffo MC, Torres A, Paul T, Dimarco RD, et al. 2017. Ecology and management of invasive Pinaceae around the world: progress and challenges. Biol. Invasions 19(11):3099-3120

Nuñez MA, Pauchard A. 2010. Biological invasions in developing and developed countries: Does one model fit all? Biol. Invasions 12(4):707-14

O’Dowd DJ, Green PT, Lake PS. 2003. Invasional "meltdown” on an oceanic island. Ecol. Lett. 6(9):812-17

Padmanaba M, Corlett RT. 2014. Minimizing risks of invasive alien plant species in tropical production forest management. Forests 5(8):1982-98

Padmanaba M, Tomlinson KW, Hughes AC, Corlett RT. 2017. Alien plant invasions of protected areas in Java, Indonesia. Sci. Rep. 7:9334

Pan Y, Birdsey RA, Fang J, Houghton R, Kauppi PE, et al. 2011. A large and persistent carbon sink in the world's forests. Science 333:988-93

Peh KS. 2010. Invasive species in Southeast Asia: the knowledge so far. Biodivers. Conserv. 19:1083-99

Pejchar L, Lepczyk CA, Fantle-Lepczyk JE, Hess SC, Tracy Johnson M, et al. 2020. Hawaii as a microcosm: Advancing the science and practice of managing introduced and invasive species. Bioscience 70(2):184-93

Phumthum M, Srithi K, Inta A, Junsongduang A, Tangjitman K, et al. 2018. Ethnomedicinal plant diversity in Thailand. J. Ethnopharmacol. 214:90-98

Povak NA, Hessburg PF, Giardina CP, Reynolds KM, Heider C, et al. 2017. A watershed decision support tool for managing invasive species on Hawai'i Island, USA. For. Ecol. Manage. 400:300-320

Pyšek P, Jarošík V, Hulme PE, Pergl J, Hejda M, et al. 2012. A global assessment of invasive plant impacts on resident species, communities and ecosystems: The interaction of impact measures, invading species' traits and environment. Glob. Chang. Biol. 18(5):1725-37

Pyšek P, Richardson DM. 2006. The biogeography of naturalization in alien plants. $J$. Biogeogr. 33:2040-50

Ramaswami G, Kaushik M, Prasad S, Sukumar R, Westcott D. 2016. Dispersal by generalist frugivores affects management of an invasive plant. Biotropica 48(5):638-44

Rejmánek M. 1996. Species richness and resistance to invasions. In Biodiversity and Ecosystem Processes in Tropical Forests, eds. G Orians, R Dirzo, JH Cushman, pp. 153-72. Springer-Verlag

Ricciardi A, Iacarella JC, Aldridge DC, Blackburn TM, James T, et al. 2021. Four priority areas to advance invasion science in the face of rapid environmental change. Environ. Rev. In press 
Robinson CJ, Smyth D, Whitehead PJ. 2005. Bush tucker, bush pets, and bush threats: Cooperative management of feral animals in Australia's Kakadu National Park. Conserv. Biol. 19(5):1385-91

Rogers HS, Buhle ER, HilleRisLambers J, Fricke EC, Miller RH, Tewksbury JJ. 2017. Effects of an invasive predator cascade to plants via mutualism disruption. Nat. Commun. 8:6-13

Russell JC, Holmes ND. 2015. Tropical island conservation: Rat eradication for species recovery. Biol. Conserv. 185:1-7

Sardain A, Sardain E, Leung B. 2019. Global forecasts of shipping traffic and biological invasions to 2050. Nat. Sustain. 2(4):274-82

Sax DF. 2001. Latitudinal gradients and geographic ranges of exotic species: implications for biogeography. J. Biogeogr. 28:139-50

Schemske DW, Mittelbach GG, Cornell H V., Sobel JM, Roy K. 2009. Is there a latitudinal gradient in the importance of biotic interactions? Annu. Rev. Ecol. Evol. Syst. 40:245-69

Seebens H, Bacher S, Blackburn TM, Capinha C, Dawson W, et al. 2021. Projecting the continental accumulation of alien species through to 2050. Glob. Chang. Biol. 21(7):970-82

Seebens H, Essl F, Dawson W, Fuentes N, Moser D, et al. 2015. Global trade will accelerate plant invasions in emerging economies under climate change. Glob. Chang. Biol. 21(11):4128-40

Shea K, Chesson P. 2002. Community ecology theory as a framework for biological invasions. Trends Ecol. Evol. 17(4):170-76

Silvério D V., Brando PM, Balch JK, Putz FE, Nepstad DC, et al. 2013. Testing the Amazon savannization hypothesis: Fire effects on invasion of a neotropical forest by native cerrado and exotic pasture grasses. Philos. Trans. R. Soc. B Biol. Sci. 368(1619):12-14

Simberloff D. 1995. Why do introduced species appear to devastate islands more than mainland areas? Pacific Sci. 49(1):87-97

Simonsen AK, DInnage R, Barrett LG, Prober SM, Thrall PH. 2017. Symbiosis limits establishment of legumes outside their native range at a global scale. Nat. Commun. 8:19

Singh HP, Batish DR, Dogra KS, Kaur S, Kohli RK, Negi A. 2014. Negative effect of litter of invasive weed Lantana camara on structure and composition of vegetation in the lower Siwalik Hills, northern India. Environ. Monit. Assess. 186(6):3379-89

Sitepu BS. 2020. Diversity and management of invasive plants in Samboja Research Forest, Kalimantan Timur. J. Sylva Lestari 8(3):351-365

Soliman T, Macleod A, Mumford JD, Nghiem TPL, Tan HTW, et al. 2016. A regional decision support scheme for pest risk analysis in Southeast Asia. Risk Anal. 36(5):90413

Soudzilovskaia NA, van Bodegom PM, Terrer C, van't Zelfde M, McCallum I, et al. 2019. Global mycorrhizal plant distribution linked to terrestrial carbon stocks. Nat. Commun. 10(1):1-10

Steidinger BS, Crowther TW, Liang J, Van Nuland ME, Werner GDA, et al. 2019. Climatic controls of decomposition drive the global biogeography of forest-tree symbioses. Nature 569(7756):404-8

Suarez A V., McGlynn TP, Tsutsui ND. 2009. Biogeographic and taxonomic patterns of introduced ants. In Ant Ecology, eds. L Lach, CL Parr, KL Abbott, pp. 233-44. New York, USA: Oxford University Press

Taylor HR, Radford IJ, Price C, Grierson P. 2018. Low resource availability limits weed invasion of tropical savannas. Biol. Invasions 20(4):861-75

Tebboth MGL, Few R, Assen M, Degefu MA. 2020. Valuing local perspectives on invasive 
species management: Moving beyond the ecosystem service-disservice dichotomy. Ecosyst. Serv. 42:101068

Tedersoo L, Bahram M, Põlme S, Kõljalg U, Yorou NS, et al. 2014. Global diversity and geography of soil fungi. Science 346(6213):1256688

Teo DHL, Tan HTW, Corlett RT, Wong CM, Lum SKY. 2003. Continental rain forest fragments in Singapore resist invasion by exotic plants. J. Biogeogr. 30:305-10

van der Heijden MGA, Martin FM, Selosse MA, Sanders IR. 2015. Mycorrhizal ecology and evolution: The past, the present, and the future. New Phytol. 205(4):1406-23

van Kleunen M, Weber E, Fischer M. 2010. A meta-analysis of trait differences between invasive and non-invasive plant species. Ecol. Lett. 13:235-45

van Kleunen M, Xu X, Yang Q, Maurel N, Zhang Z, et al. 2020. Economic use of plants is key to their naturalization success. Nat. Commun. 11(1):3201

Veldman JW, Mostacedo B, Peña-Claros M, Putz FE. 2009. Selective logging and fire as drivers of alien grass invasion in a Bolivian tropical dry forest. For. Ecol. Manage. 258(7):1643-49

Veldman JW, Putz FE. 2010. Long-distance dispersal of invasive grasses by logging vehicles in a tropical dry forest. Biotropica. 42(6):697-703

Vilà M, Espinar JL, Hejda M, Hulme PE, Jarošík V, et al. 2011. Ecological impacts of invasive alien plants: a meta-analysis of their effects on species, communities and ecosystems. Ecol. Lett. 14:702-8

Vitousek PM., Walker LR. 1989. Biological invasion by Myrica faya in Hawai'i: Plant demography, nitrogen fixation, ecosystem effects. Ecol. Monogr. 59(3):247-65

Vreysen MJB, Saleh KM, Ali MY, Abdulla AM, Zhu ZR, et al. 2000. Glossina austeni (Diptera: Glossinidae) eradicated on the island of Unguja, Zanzibar, using the sterile insect technique. J. Econ. Entomol. 93(1):123-33

Waddell EH, Banin LF, Fleiss S, Hill JK, Hughes M, et al. 2020a. Land-use change and propagule pressure promote plant invasions in tropical rainforest remnants. Landsc. Ecol. 35(9):1891-1906

Waddell EH, Chapman DS, Hill JK, Hughes M, Bin Sailim A, et al. 2020b. Trait filtering during exotic plant invasion of tropical rainforest remnants along a disturbance gradient. Funct. Ecol. 34:2584-97

Wardle DA, Bardgett RD, Callaway RM, van der Putten WH. 2011. Terrestrial ecosystem responses to species gains and losses. Science 332:1273-77

Witt A, Beale T, van Wilgen BW. 2018. An assessment of the distribution and potential ecological impacts of invasive alien plant species in eastern Africa. Trans. R. Soc. South Africa 73(3):217-36

Wyckhuys KAG, Lu Y, Zhou W, Cock MJW, Naranjo SE, et al. 2020. Ecological pest control fortifies agricultural growth in Asia-Pacific economies. Nat. Ecol. Evol. 4(11):1522-30

\section{TERMS AND DEFINITIONS}

1. Non-native: species that are brought outside of their native range by human activities; alternatively termed alien, exotic, introduced, or non-indigenous

2. Naturalized: non-native species that have established self-replacing populations 
3. Invasive species: naturalized species that spread from the original sites of introduction and cause ecological or economic impacts

4. Continental: land that is/was connected to one of the seven continents

5. Oceanic island: formed without any land-based connection to continents

6. Propagule pressure: the rate at which new individuals arrive in a given area

7. Savanna: grassland with occasional woody plants

8. Cerrado: largest savanna region in South America

9. Niche saturation: all available niches have been occupied

10. Niche packing: a determinant of the number species present that could potentially occupy a given niche space

11. Mycorrhiza: mutualistic plant-fungal symbiosis occurring at the roots of plants

12. Arbuscular mycorrhiza: mycorrhiza where the fungus form tree-like structures within plant root cells

13. Ectomycorrhiza: mycorrhiza where the fungus colonises intercellular root spaces and forms a mantle around the root tip

14. Non-equilibrium: the state where the population or biomass of organisms is expected to change directionally given the available resources

15. C4: photosynthetic pathway where a four-carbon sugar is the first product of carbon fixation

16. Invasion debt: additional invasion that is expected to occur in the future given the current conditions

17. Biosecurity: measures that prevent the introduction and spread of harmful organisms 

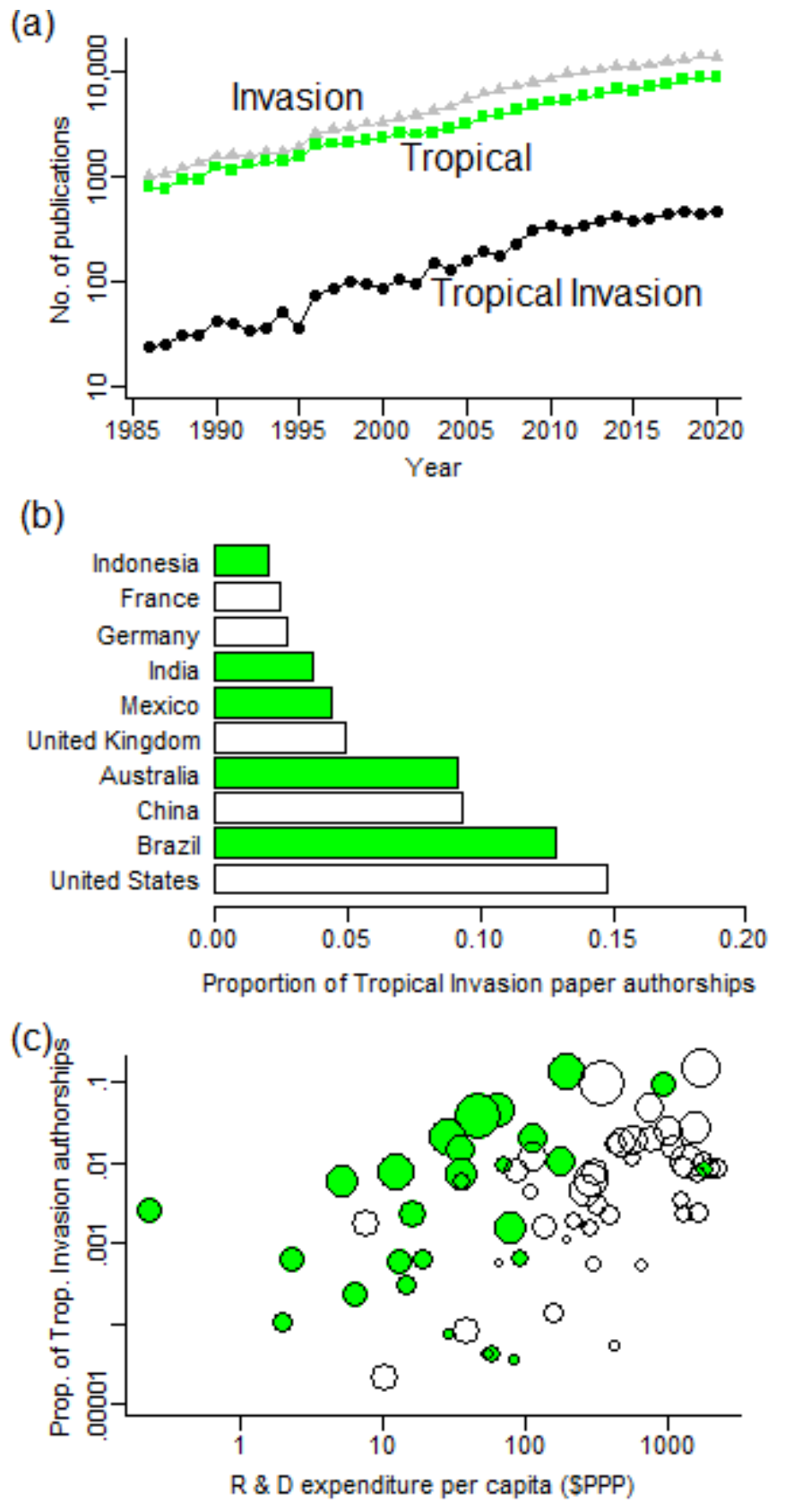

Figure 1. (a) Number of papers published in invasion biology (gray triangles), tropical biology (green squares), and tropical invasion biology (black circles) from 1986 to 2020. Note that the y-axis is in the logarithmic scale. (b) Top 10 countries in terms of the mean proportion of affiliations on all tropical invasion biology papers published from 2017 to 2020 that belong to these countries (tropical: green; non-tropical: white). (c) The relationship between countries' mean proportion of affiliations on all tropical invasion biology papers published from 2017 to 2020 (y-axis) versus the per capita research and development (' $\mathrm{R} \&$ 
D') expenditure corrected for purchasing power parity (\$PPP) in 2017 (x-axis), population size (diameter of circle proportional to log-transformed population), and whether the country is tropical (green) or not (white). See Supplemental Information for details. 


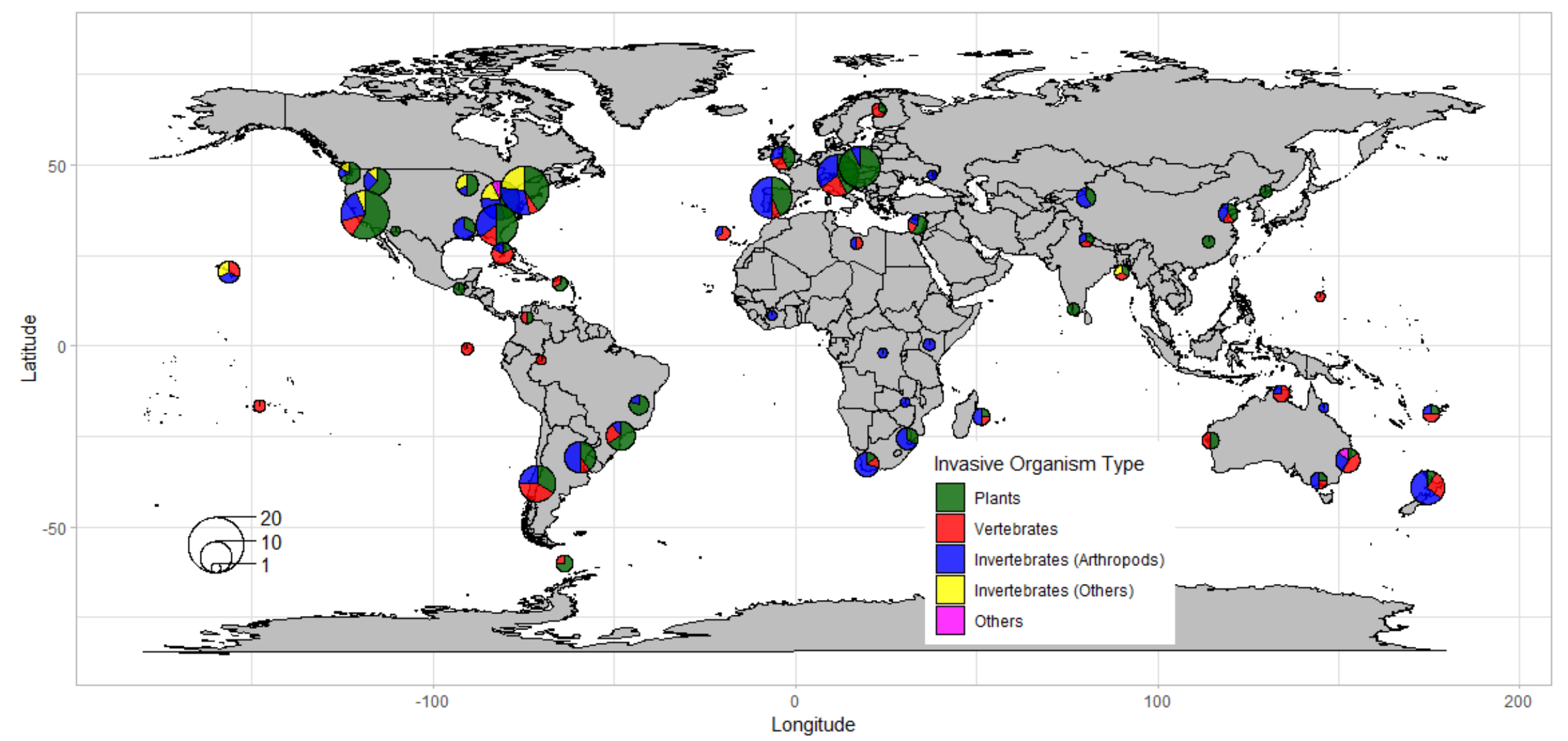

Figure 2. Geographical distribution of experimental or observational studies of invasive organisms published in Biological Invasions and Neobiota from 2019-2020. Sizes of pie charts is proportional to the number of unique studies at that locality while colors indicate the types of invasive organism studied. See Supplemental Information for details. 


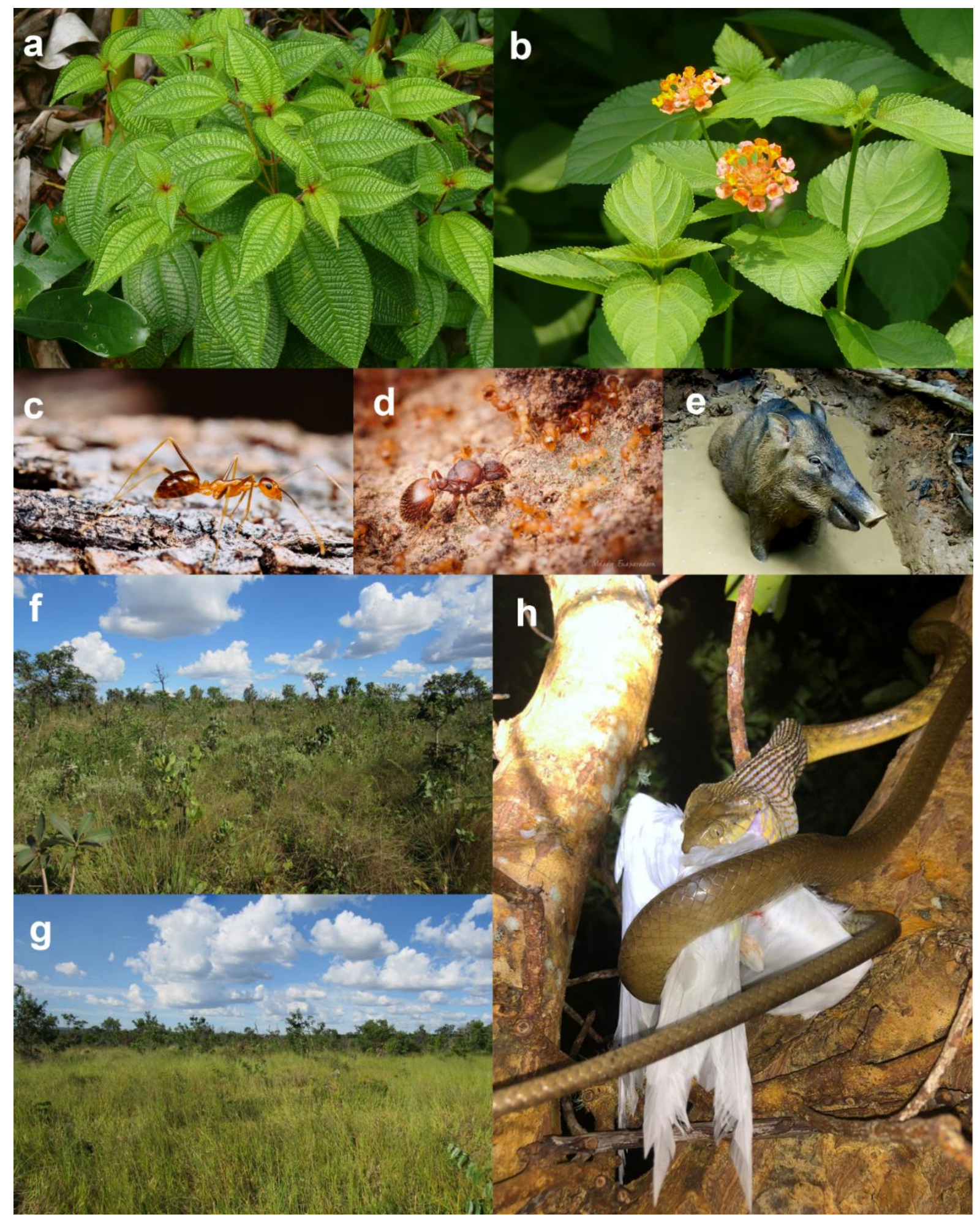

Figure 3. Examples of successful invaders in the tropics. (a) Miconia crenata and (b) Lantana camara have animal-dispersed fruits (photos: Michael Padmanaba). Two invasive tropical ant species: (c) the yellow crazy ant, Anoplolepis gracilipes, and (d) the little fire ant,

Wasmannia auropunctata, queen and workers (photos: Melody Euaparadorn). (e) A wild pig, 
Sus scrofa, wallowing in mud (photo: Nick Baker). Brazilian savanna, or cerrado, (f) before and (g) after invasion by Urochloa brizantha (photos: Gabriella Damasceno). (h) A brown tree snake, Boiga irregularis, eating a bird on the oceanic island of Guam (photo: Nathan Sablan). 